\title{
EC Competition and Internal Market Law: On the Existence of a Sporting Exemption and its Withdrawal
}

\author{
Alfonso Rincón
}

\begin{abstract}
Some authors argue that there is no such a thing as a sporting exemption under EC law. However, an indepth analysis of the case law reveals that thirty years ago the European Court of Justice ("ECJ", or "Court") created an exemption specifically relating to sport. The judgment of the ECJ in Walrave established the basis for this exemption, which was confirmed and extended in Donà. Since then the exemption has been subject to the vicissitudes of legal interpretation. First of all, the Court endeavoured to contain its use, although the consequence of this was the expansion of the exemption from internal market to competition rules. This led to uncertainty and inaccuracy in the assessment of sporting practices. The ECJ reacted to the atmosphere of confusion created by the interpretation of the Walrave case and withdrew the exemption in Meca Medina. The correct test for assessing whether a sporting practice is contrary to EC law is now the proportionality test; however, further clarification is required.
\end{abstract}

THE ASSUMPTION INFORMING THIS ARTICLE IS THAT, IN CERTAIN CASES, there is a conflict between the rules governing sport and the rules regulating the internal market and competition of the European Community (EC). Two conflicting sets of rules therefore exist that have to be taken into account in the analysis set forth.

Firstly, there are the regulations of the national or international sporting bodies. Regulations imposed by these bodies are based on general principles common to all sports. FIFA, for example, has four core values: authenticity, unity, performance and integrity. ${ }^{1}$ These main values, and others, could be said to be pursued, in one way or another, by all sporting bodies. They are, however, not universal values, so each organisation, body or association will have its own variations on the theme. ${ }^{2}$ The world of sport has to be understood as one in which

\footnotetext{
${ }^{1}$ FIFA's mission, available at: <http://www.fifa.com/aboutfifa/federation/mission.html>.

2 Even small organisations such as the French Community of Belgium have their own. Its 'Charte Éthique' states that the main values of sport are 'fair-play, le respect de soi et de l'autre, le respect de l'arbitrage, le refus de tout produit dopant, l'acceptation des différences, la solidarité et l'esprit d'équipe'. See $<$ http://www.sportethique.be $>$. See another example on the website of the Canadian organisation True Sport, <http://www.truesportpur.ca> (inclusion, fairness, excellence and fun).
}

Researcher. University Institute for European Studies. CEU San Pablo University (Madrid). This article is based on the paper I gave at the Second Annual SPORT\&EU Workshop held on $6^{\text {th }}$ and $7^{\text {th }}$ July 2007 at the University of Chester. I would like to thank to those who attended the meeting for their comments. I would also like to thank the two anonymous reviewers. Any errors remain mine. 
competing and sometimes contradictory values and ethics are debated and idealised. ${ }^{3}$ However, it is essential to ensure the sporting competitions are genuine and free from any improper influence that might cast doubt over the authenticity of results. ${ }^{4}$ In order to achieve these objectives, sporting bodies issue common rules ${ }^{5}$ and international sports associations create a set of norms concerning the practice of the particular sport under their supervision (the 'rules of the game' where they establish the norms that have to be followed in every confrontation between teams or athletes). For example, FIFA considers itself to be the guardian of football and as such is bound to safeguard the Laws of the Game. ${ }^{6}$ In general all sporting bodies believe that one of their main objectives should be to adopt necessary uniform rules and regulations to hold competitions. ${ }^{7}$ Such rules are approved in order to regulate, for example, the size of the court, the composition of the ball or the design of the players' apparel. ${ }^{8}$ International federations, furthermore, have a wider remit and adopt rules concerning other areas such as the eligibility of the players for competitions ${ }^{9}$ or the transfer of players. ${ }^{10}$

The other set of rules that has to be taken into account in this analysis are the laws of the European Community concerning the internal market and competition policy. The norms of the sporting bodies may conflict with the provisions of the EC Treaty that provide for the free movement of people (Art. $39 \mathrm{EC}$ ), the freedom to provide services (Art. $49 \mathrm{EC}$ ), the prohibition of restrictive practices (Art. $81 \mathrm{EC}$ ) or of abuse of a dominant position (Art. $82 \mathrm{EC}$ ). To give an example, rules that prevent or limit a sportsman from being signed by a club may in certain circumstances conflict with the rules of the EC treaty. This conflict could result in three different scenarios. Firstly, sporting regulations could prevail over EC law. In this case, sporting associations would be able to infringe internal market and competition rules with impunity, and would benefit from the so-called sporting exemption. Secondly, EC rules could supersede sporting regulations, and sporting regulations would have to be adapted to the treaties. Thirdly, it is possible that in certain circumstances EC rules could prevail while in others sporting rules could be enforceable. The present research is focused on analysing to what extent the first option outlined above has been the case within the application of EC law to sport through the creation of a sporting exemption. An analysis will also be made as to whether there is evidence of a significant and logical shift towards the third option.

The European Court of Justice (ECJ) in the seminal Walrave (1974) judgment established what could be called a sporting exemption. Its application/existence is a major issue for the sporting bodies. This is so because while sometimes a minor change in sporting rules can be enough to comply with EC law, at other times sporting rules have to be changed quite significantly. Community institutions have already exerted a considerable indirect influence on sporting affairs when assessing the compatibility of sporting rules with the Treaty provisions on freedom of movement or competition law. ${ }^{11}$ For example, in 2002 FIFA was forced to modify its rules regarding international transfers to comply with the provisions of the EC Treaty. ${ }^{12}$ Moreover there is a very important case pending before the Court of Justice in which FIFA's rules governing the release of players for international representative

\footnotetext{
${ }^{3}$ Eitzen (1999), quoted by Wachs, Faye, Berkshire, 'Values and Ethics', (2005) Encyclopaedia of World Sport 4, p. 1662.

${ }^{4}$ Arnaut, J.L. (2006),Independent European Sport Review, p. 37.

${ }^{5}$ See McFee G., (2004), Sport, Rules and Values: Philosophical Investigations Into the Nature of Sport (Routledge) for a critical analysis of the regulation of sport.

${ }^{6}$ FIFA's mission, $\mathrm{n} 1$ above.

${ }^{7}$ FINA Constitution (2001), C.5.4 for Swimming, Open Water Swimming, Diving, Water Polo, Synchronised Swimming and Masters.

8 International Handball Federation, Rules of the Game, (2005), rules 1, 3 and 4.

${ }^{9}$ International Handball Federation, Player Eligibility Code (2006).

${ }^{10}$ See FIFA, Regulations for the Status and Transfer of Players (2005); or International Handball Federation, Regulations for Transfer between Federations (2006).

${ }^{11}$ Van den Bogaert, S. and Vermeersch, A. (2006), 'Sport and the EC Treaty: a tale of uneasy bedfellows?', European Law Review 31, p. 826.

${ }^{12}$ European Commission, 'Commission closes investigations into FIFA regulations on international football transfers', (2002) IP/02/824.
} 
matches are being scrutinised..$^{13}$ Besides, Regulation 1/2003 could bring more cases in which sporting practices are challenged on the basis of competition rule infringements. In this connection the sporting movement has pushed for the recognition of the autonomy of sport, whereby sport, as a civil and social movement that emerged at the margins of public authority regulation, should remain self-governed by the structures and bodies that have done so over the years. ${ }^{14}$ The sporting bodies want to avoid a 'juridification' (judiciarisation, in French) of sport. ${ }^{15}$ Some authors have identified, within the EC, an advocacy coalition of protectionists (including sports federations) who want sport to be partially or fully exempt from EC law. ${ }^{16}$ The sporting exemption created by the ECJ in Walrave accords with what the sporting bodies have in mind when they ask for autonomy. ${ }^{17}$ The substantiation of this line of reasoning would place the sporting bodies out of the reach of the EC Treaty. The case law nevertheless does not give a clear indication of the conditions that have to be met for the exemption to apply. Through the years, the exemption framed in Walrave has been subject to various interpretations. Firstly the European Court of Justice tried to conceal it or contain its expansion (phase 2 below). Then, however, the European Commission acknowledged the existence of the exemption and used it in its competition law analysis (phase 3 below). Recently the European Court of Justice reacted to the atmosphere of confusion created by the interpretation of the Walrave case and withdrew the exemption (phase 4 below). However the way forward is not clear and there is a need for further clarification. In this connection the international sports federations and other incumbents are calling for legal certainty regarding the application of the acquis communautaire. However, legal certainty should not be seen as a synonym for exemption. Legal certainty means that people are able to plan their lives, secure in the knowledge of the legal consequences of their actions. ${ }^{18}$ This should not be confused with being secure in the knowledge that their actions will not have any legal consequences. The following pages contain a description of the various phases specified above. In addition, an explanation is given of the evolution of case law towards a more sophisticated appraisal based on proportionality.

\section{Phase 1: Creation: Once Upon a Time the ECJ Created a Sporting Exemption}

\section{The Configuration of the Exemption}

In 1974 the ECJ was for the first time confronted with a case in which the compatibility of the sporting rules with the EC Treaty was put into question. The rules of the Union Cycliste Internationale, relating to medium-distance world cycling championships behind motorcycles, provided that the pacemaker must be of the same nationality as the stayer. Mr. Walrave and Mr. Koch considered that the norm was contrary to the rules of the internal market (now Arts. 39 and $49 \mathrm{EC}$ ). The answer seemed to be clear. Sport should be subject to EC Law. However in certain cases sporting rules have to engage in forms of discrimination for the benefit of sport. International federations can be said to have a kind of special legitimacy when adopting rules for the good of the game that may be contrary to EC law. These rules are justifiable and on this basis cannot be challenged successfully. The judgment of the ECJ in Walrave, despite recognising that sport is subject to Community law in so far as it constitutes an economic activity, established the basis for the sporting exemption, stating that European Law 'does not affect the composition of sport teams, in particular national teams, the formation of which is a question of purely sporting interest and as such has

\footnotetext{
${ }^{13}$ Case C-243/06, SA Sporting du Pays de Charleroi, G-14 Groupement des clubs de football européens/ FIFA (Oulmers).

${ }_{14}$ Garcia, B. (2007), 'From regulation to governance and representation: Agenda-setting and the EU's involvement in sport", Entertainment and Sports Law Journal, vol. 5, n० 1.

15 Dubey, J.P. and Dupont, J.L. (2002), 'Droit européen et sport: Portrait d'une cohabitation', Journal des tribunaux, Droit Européen 85, p. 15. For an analysis of the process of juridification see Gardiner, S \& Felix, A., 'Juridification of the Football Field: Strategies for Giving Law the Elbow', (1995) Marquette Sports Law Journal 189.

${ }^{16}$ Parrish, R. (2002), 'Football's Place in the Single European Market', Soccer and Society, vol. 3, issue 1, p. 3.

${ }_{17}$ Greenfield, S \& Osborn, G. (2003), 'The Role of Law within Sport', available at <www.idrottsforum. org >.

${ }^{18}$ Craig, P. and de Búrca, G. (2003), EU Law. Texts, Cases and Materials (Oxford), p. 380.
} 
nothing to do with economic activity'. ${ }^{19}$ The exemption was confirmed and extended in Donà (1976), were the Court affirmed that the Treaties 'do not prevent the adoption of rules or of a practice excluding foreign players from participation in certain matches for reasons which are not of an economic nature, which relate to the particular nature and context of such matches and are thus of sporting interest only, such as, for example, matches between national teams from different countries'. ${ }^{20}$ The wording of the ECJ rulings is not unambiguous. Notwithstanding it can be interpreted as establishing a sporting exemption.

\section{The Nature of the Exemption}

\section{The Framework}

It is firstly necessary to distinguish between the sporting exemption and the case law of the European Court of Justice on the existence of an economic activity. It is assumed that any activity is subject to Community law only in so far as it constitutes an economic activity within the meaning of Article 2 of the Treaty. ${ }^{21}$ The analysis of the reasoning in Walrave and Donà could lead to the conclusion that the ECJ had considered that the sporting rule was not subject to EC law because there was no economic activity. ${ }^{22}$ However the judgment of the ECJ cannot be construed in this way. In fact, the Court is not talking about the existence of economic activity but about a question of purely sporting interest (Walrave) or reasons which are of a particular nature (Donà). The Court therefore does not analyse the economic content of the sporting activity. It analyses the basis upon which the sporting rule was approved. The assessment is based on the interests and reasons of the sporting bodies, not on the economic effects of the rules or on the economic content of the sporting activity. In this connection it is interesting to look at the case law of the ECJ relating to the existence of an economic activity, to see how far these judgments are from the findings of Walrave. In Levin (1982) the Court affirmed that the concept of 'worker' in the sense of the EC Treaty should include any employed person even if such person is paid a remuneration lower than the minimum guaranteed remuneration in the sector. ${ }^{23}$ Accordingly the Treaty only does not cover those activities that are on such a small scale as to be regarded as purely marginal and ancillary ${ }^{24}$. The cases of Walrave or Donà could not be seen as having a marginal and ancillary economic content. The exclusion from the scope of the Treaty of Walrave was not based on a detailed analysis of the economic content of the activity but in the conviction of the European Court of Justice that the sporting rule could not be eliminated. By this time sporting activities already had an economic content; sport was already a show business. ${ }^{25}$ It has been reported that in the UK players were authorised to receive a payment as early as $1885 .{ }^{26}$ In the early 1960 s, football players' average wages in the United Kingdom were $£ 20$ per week. In 1968 Manchester United had a transfer value of $£ 110,000 .{ }^{27}$ The Court could not have said that the sport was not an economic activity. The analysis of the case law by Advocate General Lenz in Bosman supports the view that the ECJ created an exemption, as he affirmed that the Walrave and Donà cases had established 'a sort of limited exception as to scope'. ${ }^{28}$ In fact, the link between the sporting exemption and the concept of economic activity can only be found in Walrave whereas the remaining case law on the sporting

\footnotetext{
${ }^{19}$ Case 36/74, Walrave [1974] ECR 571, § 8.

${ }^{20}$ Case 13/76, Donà [1976] ECR 479, § 14.

${ }^{21}$ Case 36/74, Walrave, $\mathrm{n} 19$ above, $\S 4$.

22 O'Keeffe, D. and Osborne, P., 'L'affaire Bosman: un arrêt important pour le bon fonctionnement du Marché unique européen', (1996) Revue du Marché Unique Européen 1, p. 23.

${ }^{23}$ Case 53/81, Levin [1982] ECR 1035, § 16.

24 ibid, § 17. See also cases 139/85, Kempf [1986] ECR 1741 and 196/87, Steymann [1988] ECR 6159.

${ }^{25}$ See Forlati Piochio, L., 'Discriminazioni nel settore sportivo e Comunitá Europee', (1976) Rivista di Diritto Internazionale, vol. LIX, fasc. 4, p. 753 and Telchini, I., 'Commento: La Sentenza 12 dicembre 1974 nella causa 36-74 e le attivitá sportive nell'ambito comunitario', (1975) Rivista de Diritto Europeo 2, p. 133.

${ }^{26}$ McArdle, D, 'One Hundred Years of Servitude: Contractual Conflict in English Professional Football before Bosman', (2000) Web Journal of Current Legal Issues 2.

${ }^{27}$ Dart, T. (2000), 'Playing in a different league', in Hamil, S., Michie, J., Oughton, C. and Warby, S. (eds.), Football in the Digital Age, available at http://www.football-research.org/fitda/footballinthedigitalage.htm.

${ }^{28}$ AG Lenz opinion in case 415/93, Bosman [1995] ECR I-4921, § 139.
} 
exemption, including Donà ${ }^{29}$, does not link the possibility of exempting the sporting rules with the economic content of the activity.

\section{The Basis of the Exemption}

The discussions about the existence of the sporting exemption have been centred very much on the concept of the purity of the sporting activity. In Walrave the Court made reference to 'purely sporting interest' whereas in Donà the Court talked about 'sporting interest only'. However it is difficult, if not impossible, to assess whether an activity is 'purely sporting', 'sporting but not economic' or 'economic but not sporting'. Furthermore, the Court does not say what should be analysed in order to grant an exemption - the specific activity, the reasons on which the sporting practice is based or the nature of the sporting activity. It can be said that the sporting element does not preclude in any way the possibility of any practice having economic effects. The definition of 'pure' is, according to the dictionary, 'free from anything of a different, inferior, or contaminating nature; or free from extraneous matter'. It is wrong to say that the non-existence of economic effects could be based on purity of interests. ${ }^{30}$ In fact these days it is very difficult, if not impossible, to find a rule which is in this sense pure. The analysis should be focused only on the existence or not of an economic element, as the Court did in Levin, Kempf (1986) or Steymann (1988). ${ }^{31}$ Other options are contrary to an ordered analysis of sporting practices under EC law.

\section{Phase 2: Contention (confusion)}

Since Walrave and Donà, the European Court of Justice has refused to apply the sporting exemption and rejected the application of the Walrave doctrine. In fact, as has been widely recognised, Bosman ${ }^{32}$ ended an age of innocence when football [we could say, sport ${ }^{33}$ ] blithely assumed that it was immune from the intervention of law. ${ }^{34}$ However, the view of the Court of Justice is not straightforward. The ECJ recognises that Walrave and Donà had established a restriction on the scope of the provisions concerning freedom of movement for persons. ${ }^{35}$ This amounts to affirming that the free movement rules can be overruled in certain specific cases; or at least that in certain circumstances the Treaty does not apply to sport activities. The key is therefore in finding out exactly when the conditions for granting the sporting exemption are met. But the court is silent on this. It repeats again and again the extract from Donà. There is no explanation or definition of the necessary elements for determining the existence of a limitation of the scope of the Treaty. In the judgments adopted after Donà the Court rejects the application of its previous case law without giving a well founded reasoning. In fact, the main problem with the wording of its analysis is that the Court does reject the use of the sporting exemption, but on the basis of different arguments, none of them convincing. It employs ambiguous reasoning that does not clarify the question.

\footnotetext{
${ }^{29}$ In Walrave the Court said that the practice had nothing to do with economic activity. Case 13/76, Donà, $\mathrm{n}$ 20 above, $\S 14$ refers only to the economic nature of the reasons, not to the economic content of the activity. ${ }^{30}$ There are however some similarities between Walrave and case 344/87, Bettray [1989] ECR 1621, § 17, where the Court affirmed that 'work under the Social Employment Law cannot be regarded as an effective and genuine economic activity if it constitutes merely a means of rehabilitation or reintegration for the persons concerned'.

${ }^{31} \mathrm{n} 24$ above.

${ }^{32}$ Case 415/93, Bosman [1995] ECR I-4921.

${ }^{33}$ Schmeilzl, B., 'Lilia Malaja and Maros Kolpak: Unrestricted professional Athletes within Europe and beyond? Current Developments and Future Perspectives in the Area of Freedom of Movement in Sports', (2003) available at www.grafpartner.com, p. 21, affirms that after Bosman most sports organisations - while grinding their teeth - modified their rules to comply with the judgment.

${ }^{34}$ Foster, K. (2000), 'European Law and Football: Who's in Charge?', Soccer and Society 1, p. 39.

${ }^{35}$ Case 415/93, Bosman, n 32 above, § 127.
} 
The Court affirms that the exemption must remain limited to its proper objective. ${ }^{36}$ Case law, according to the Court, cannot be relied upon to exclude the whole of a sporting activity from the scope of the Treaty. ${ }^{37}$ It is clear that one cannot place a sporting activity outside the limits of EC law. But the Court does not say what the objective of the exemption is, making it impossible to define the limits of the exemption. On the other hand the Court links Walrave and Donà with the task of severing the economic aspects from the sporting aspects of football. ${ }^{38}$ As has been said, in these two cases the limitation of the scope of the Treaty was based on the interests of and reasons given by the sporting bodies. The existence of the economic element was not discussed. The same happens in Bosman, where the Court does accept the existence of an economic activity. Moreover in Deliège the Court analysed the concept of economic activity as a completely different issue from the evaluation of the sporting exemption. In paragraphs 41 to 44 of the judgment the Court made references to Walrave, Donà and the Declaration on Sport (Declaration 29) annexed to the final act of the Conference which adopted the text of the Amsterdam Treaty. Its conclusion was that such competitions could not be treated as events which might fall outside the scope of Community law. ${ }^{39}$ In paragraphs 49 to 59 it verified whether an activity of the kind engaged in by Ms Deliège was capable of constituting an economic activity within the meaning of Article 2 of the Treaty. The concept of economic activity is not therefore related to the sporting exemption as analysed in Walrave.

The Court has used another argument to reject the application of the exemption which has introduced more uncertainty as to its scope. In Bosman it considered that the exemption could not be used in the case of nationality clauses because these did not concern specific matches between teams representing their countries but applied to all official matches between clubs and thus to the essence of the activity of professional players. ${ }^{40}$ The sporting exemption therefore applies only in cases concerning national teams. This is the reasoning in Deliège. The Court rejected the application of Walrave and Donà because the competition could not be treated as an event between national teams. ${ }^{41}$ However, in Donà, the reference to 'matches between national teams from different countries' was used as an example. Here, again, a new argument used to reject the applicability of the exemption only caused more confusion. What is, however, unmistakable in the wording of the judgments is that the ECJ was trying to hide its own findings. It seems that the Court wanted Walrave and Dona not to be taken into account. It tried to contain the use of the exemption. Lehtonen is a clear example of this behaviour. The Court did not even consider the application of the sporting exemption to the case. It only mentioned its previous case law (Donà) and rejected its use without giving any explanation. ${ }^{42}$ It seemed that the Court did not even want to talk about the subject; all it wanted to do was to forget it.

\section{Phase 3: Expansion}

During the eighties, the nineties and the first years of the new century, the Commission had to deal with many cases related to the application of the rules of the Treaty, in particular Articles 81 and 82 EC, to sporting activities. In 1999 the Commission recognised that it was examining sixty pending cases on the application of European Union competition rules to sports. ${ }^{43}$ DG Competition was not sure of the correct way to deal with these cases. There were two main approaches to analyse the behaviour of sporting bodies. On the one hand sport could be considered to fall outside of the Treaty (Walrave). On the other, sporting practices could be subject to a proportionality test (DLG and Wouters and the case law on

\footnotetext{
${ }^{36} \mathrm{ibid}, \S 76$ and 127.

37 ibid, § 76, see also Cases 51/96 and 191/97, Deliège [2000] ECR I-2549, § 43.

${ }^{38}$ Case 415/93, Bosman, n 32 above, $\$ 76$.

${ }^{39}$ Cases 51/96 and 191/97, Deliège, n 37 above, §§ 44.

${ }^{40}$ Case 415/93, Bosman, n 32 above, § 128.

${ }^{41}$ Cases 51/96 and 191/97, Deliège, n 37 above, $\S 44$.

${ }^{42}$ Case 176/96, Lehtonen [2000] ECR I-2681, §§ 34 and 36.

43 European Commission (1999), 'Commission debates application of its competition rules to sports', IP/99/133.
} 
objective justifications, see below). The Commission did have a trail to follow. As has been pointed out, in the case law the first option had been in retreat since Donà. Besides the trail left by the Court, the Walrave doctrine lacks a logical basis. The Commission should therefore use the proportionality test. However it did not have a clear view of what test should be used. There was no legal certainty in the application of EC law to sport. Although some clues can be ascertained, the practice of the ECJ created confusion in the way EC law should be applied to sports associations. The line of reasoning followed by the ECJ was not clear enough. This ambiguity generated a process of expansion of the sporting exemption to other areas of EC law, for the European Commission introduced the sporting exemption in its analysis concerning EC competition law.

\section{The European Commission Doubts but Finally Embraces the Sporting Exemption}

The use of the Walrave case law was one of the possible choices while applying EC law to sport. The Commission affirmed that there were various categories of sporting organisations' practices ${ }^{44}$ :

'1) rules to which, in principle, Article 85(1) of the EC Treaty does not apply, given that such rules are inherent to sport and/or necessary for its organisation;

(2) rules which are, in principle, prohibited if they have a significant effect on trade between Member States;

(3) rules which are restrictive of competition but which in principle qualify for an exemption, in particular rules which do not affect a sportsman's freedom of movement inside the EU and whose aim is to maintain the balance between clubs in a proportioned way by preserving both a certain equality of opportunities and the uncertainty of results and by encouraging recruitment and training of young players [...].'45

It could be affirmed that the first category concerns the application of the proportionality test that will be explained below, whereas the third category concerns the application of the exemption included in Art. 81(3) EC. Here the sporting exemption based on Walrave is not considered as a possibility. However, successive decisions taken by the European Commission will reveal that the Commission had endorsed the sporting exemption.

In the following years the Commission expressed its intention to give the sporting bodies room for manoeuvre. In a case concerning the "at home and away from home" rule of UEFA, the Commission considered that UEFA had 'exercised its legitimate right of self-regulation as a sports organisation in a manner which cannot be challenged by the Treaty's competition rules'. ${ }^{46}$ The rule stated that each club must play its home match at its own ground. According to the Commission, this was a sports rule that did not fall within the scope of the Treaty's competition rules. In 2002, Commissioner Monti stated that '[s]porting regulations such as the way championships are organised, the way a coach structures his football team, how a referee rules the field, whether a judo player is selected to represent his or her country at the Olympic Games or the suspension of a swimmer for having taken doping substances is not the business of the Commission's competition department and when we have received complaints we rejected them' ${ }^{47}$ The text reveals that the Commission does not want to interfere in the activities of the international federations. The last words of the sentence lead us to another seminal case concerning the issue of the sporting exemption, Meca Medina. In Meca Medina the Commission analysed the anti-doping rules of the International Swimming

\footnotetext{
44 Parrish, R. (2003), Sports Law and Policy in the European Union (Manchester University Press), p. 152 considers the Commission paper to be a representation of the separate territories approach.

${ }^{45}$ European Commission, 'Commission debates application of its competition rules to sports', $\mathrm{n} 43$ above.

${ }^{46}$ European Commission, 'Limits to application of Treaty competition rules to sport: Commission gives clear signal', (1999) IP/99/965.

${ }^{47}$ Monti, M. (2002), 'Competition and the Consumer: What are the aims of European Competition Policy?', SPEECH/02/79.
} 
Federation. It affirmed that the rules did not fall foul of the prohibition under Article $81 \mathrm{EC}$. This finding was based on Wouters (see below). ${ }^{48}$ The Commission analysed whether the anti-doping rules were linked to the development of the competition and whether they were necessary. ${ }^{49}$ It concluded that the rules were justified, reasonable and well-balanced. ${ }^{50}$ However, during the procedure before the European Court of First Instance (CFI), the Commission stated that its decision was based on Walrave and Donà, and therefore on the purely sporting nature of the anti-doping rules at issue..$^{51}$ The sporting exemption had been accepted by DG Competition.

The Alternative Method for Analysing the Compatibility of Sporting Practices with EC Law: The Proportionality Test

In the introduction three possible outcomes of the conflict between EC law and sporting rules were pointed out. The third option could be formulated as follows: The sporting rules are not contrary to EC law if they are reasonable. If they are not, the rules are illegal and shall be modified or eliminated. This proportionality test is followed regularly in the application and analysis of the restrictions of the internal market and EC rules on competition. In competition law the test is recognised as the qualitative appreciability test. In relation to internal market rules the test has been framed in the form of mandatory requirements of general interest or objective justifications. The rationale for this is that many rules which regulate trade are also capable of restricting trade, yet some of these rules serve objectively justifiable purposes..$^{52}$

\section{The Proportionality Test in Competition Law}

In February 2002 the Court adopted a very important judgment that will influence the analysis of sporting practices. It affirmed that a regulation adopted by the Bar of the Netherlands, concerning partnerships between Members of the Bar and members of other professions, did not infringe Article 81(1) of the Treaty, since that body could reasonably have considered that that regulation, despite the restrictive effects on competition that are inherent in it, was necessary for the proper practice of the legal profession, as organised in the Member State concerned. ${ }^{53}$ One of the judgments in which the Court based its findings was DLG. In that case the Court analysed a provision in the statutes of a cooperative purchasing association, forbidding its members to participate in other forms of organised cooperation. The Court held that the agreement was 'not caught by the prohibition in Article 85(1) of the Treaty, so long as the abovementioned provision is restricted to what is necessary to ensure that the cooperative functions properly and maintains its contractual power in relation to producers'.54 The findings of the Court in DLG and Wouters have been considered as the test of qualitative appreciability by which the Court assesses whether a restriction is objectively necessary to protect certain rights recognized as legitimate. If this is so the agreement escapes the application of Art. 81(1) EC. ${ }^{55}$ Some authors have established a link between the findings of Wouters and the idea of ancillarity, under which restrictions of conduct do not infringe Article 81(1) EC where they are ancillary to some other legitimate purpose. ${ }^{56}$ This appraisal is very much related to the rule of reason analysis. ${ }^{57}$

\footnotetext{
${ }^{48}$ Dec. Meca Medina y Majcen / ClO, case COMP 38158 (2002), § 43.

49 ibid, § 44.

50 ibid, § 53.

${ }^{51}$ Case T-313/02, Meca Medina v Commission [2004] ECR II-3291, § 62.

${ }^{52}$ Craig and de Búrca, n 18 above, p. 659.

${ }^{53}$ Case C-309/99, Wouters [2002] ECR I-1577, § 110.

${ }^{54}$ Case C-250/92, DLG [1994] ECR I-5641, § 45.

${ }^{55}$ Ritter, L. y Braun, W.D. (2004), European Competition Law: A Practitioner's Guide (Kluwer Law International), pp. 131-132.

${ }^{56}$ Whish, R. (2003), Competition Law (LexisNexis), p. 122.

${ }^{57}$ Marquis, M. (2007), 'O2 (Germany) v Commission and the exotic mysteries of Article 81(1) EC', European Law Review 32.
} 
This reasoning has already been applied to the analysis of sporting practices by the Advocates General in the Bosman, Deliège and Lehtonen cases. In Bosman, Advocate General Lenz asked himself about the existence of a rule of reason analysis in EC Competition Law. It was held that '[a] glance at the case-law shows [...] that in interpreting Article 85(1) [now Article 81 (1)] the Court of Justice does not proceed from a formal concept of restriction of competition, but carries out an evaluation'.58 Quoting DLG, Mr. Lenz affirmed that in view of the special features of professional football, it could be possible that certain restrictions may be necessary to ensure the proper functioning of the sector. ${ }^{59}$ In such a case the restrictions would not fall within Article 85(1) EC [now Article 81 (1)]. Further, in Deliège, Advocate General Cosmas affirmed that the legal construction of DLG must be transposed to the relationship between sport and Community competition law. He held that:

\begin{abstract}
'Applying that reasoning to this case, I also take the view that, even if they were to be regarded as reducing competition, in the sense that they prevent certain judokas from taking part in certain international tournaments, the contested rules do not fall within the scope of Article 85 [now 81] of the Treaty because they are indispensable for attaining the legitimate objectives deriving from the particular nature of judo.' ${ }^{60}$
\end{abstract}

In Lehtonen Advocate General Alber affirmed that the reasoning of DLG could be transposed, at least partially, to that case. ${ }^{61}$

Although these findings have not been confirmed by the Court (it did not answer the questions concerning the applicability of competition law to sport in Bosman, Deliège nor Lehtonen), there were basis to use the rule of reason analysis in relation with sport practices. This was what the European Commission did in ENIC. In 2000 ENIC lodged a complaint against European football's governing body UEFA concerning its 'Integrity of the UEFA Club competitions: Independence of clubs' rule. This rule, which was adopted by the UEFA Executive Committee in 1998, states that no club participating in a UEFA club competition may, either directly or indirectly, control any other club participating in the same competition. The Commission had to analyse whether the rule was contrary to EC Competition Law. On the basis of Wouters the Commission affirmed that:

'Thus the question to answer in the present case is whether the consequential effects of the rule are inherent in the pursuit of the very existence of credible pan European football competitions. Taking into account the particular context in which the rule is applied, the limitation on the freedom to act that it entails is justified and cannot be considered as a restriction of competition. ${ }^{62}$

Thus the sporting rules were not contrary to EC law because they were reasonable.

\title{
The Proportionality Test in the Rules of the Internal Market
}

In relation to internal market rules the Court applied this reasoning in Bosman ${ }^{63}$, Deliège ${ }^{64}$ and Lehtonen ${ }^{65}$ when looking for justifications of sporting rules. What is interesting in this connection is the parallel between the analysis of restrictions on competition and restrictions on free movement. ${ }^{66}$ As has been seen in Wouters, the reasoning of the Court is based on assessing whether the consequential effects that restrict competition are inherent in the

\footnotetext{
${ }^{58}$ AG Lenz opinion in Case 415/93, Bosman, n 28 above, § 268.

59 ibid, §§ 269-70.

${ }^{60}$ AG Cosmas opinion in Cases 51/96 and 191/97, Deliège [2000] ECR I-2549, § 112.

${ }^{61}$ AG Alber opinion in Case 176/96, Lehtonen [2000] ECR I-2681, § 108.

62 Dec. ENIC/ UEFA, case COMP/37 806 (2002), § 32.

$63 \S \S 105-114$ and $121-137$.

$64 \S \S 64-68$.

$65 \S \S 51-59$.

${ }^{66}$ See Mortelmans, K. (2001), 'Towards Convergence in the Application of the Rules on Free Movement and on Competition', Common Market Law Review 38.
} 
pursuit of the objectives of the rules. ${ }^{67}$ An identical analysis can be found in those cases were the Court studied the existence of an infringement of the rules of the Treaty on free movement by sport associations. In Bosman, within the analysis of the objective justifications, the Court affirmed that the nationality clauses could not be deemed to be in accordance with Article 48 [now 39] of the Treaty because, among other things, a football club's links with the Member State in which it is established cannot be regarded as any more inherent in its sporting activity than its links with its locality, town or region. ${ }^{68}$ In Deliège the Court held that:

\begin{abstract}
'In that context, it need only be observed that, although selection rules like those at issue in the main proceedings inevitably have the effect of limiting the number of participants in a tournament, such a limitation is inherent in the conduct of an international high-level sports event, which necessarily involves certain selection rules or criteria being adopted. Such rules may not therefore in themselves be regarded as constituting a restriction on the freedom to provide services prohibited by Article 59 [now Article 49] of the Treaty.'
\end{abstract}

To be inherent to the organisation of sport was enough for a sporting practice to comply with the rules of the treaty. The reasoning is similar to the reasoning followed by the Court in Wouters. Contrary to what some authors have said ${ }^{69}$, Deliège cannot therefore be compared with the findings of the Court in Walrave. In Deliège the Court applied the proportionality test, which is something that is missing in Walrave.

What is important for the purposes of this paper is that the Court has the same tool for analysing the compatibility of sporting practices with competition and free movement rules. It has been argued that in Wouters the Court was deliberately trying to reach a similar outcome under Art. 81 EC to what which would have been achieved under Art. 49 EC. ${ }^{70}$ It could be said that the Advocates General in Bosman, Deliège and Lehtonen were trying to reach a similar outcome under competition rules to what they had achieved under internal market rules. In fact, their analysis under competition law followed the same reasoning as their analysis under the internal market rules. In both cases they applied the proportionality test. They even used the same justifications for the analysis of the possible infringement of both sets of rules. ${ }^{71}$

\title{
The Judgment of the CFI in Meca Medina: An Impossible Assessment
}

Meca Medina could be seen as the epitome of the confusion in which the European institutions find themselves when they have to deal with sporting issues. The conduct of the Commission, modifying, before the CFI, its opinion on the test to be applied, was patent evidence of this confusion. The judgment of the Court of First Instance in Meca Medina could be considered, thus far, as the apex of the misleading analysis of the behaviour of sporting bodies under EC law. The core of the problem is in the choice of the CFI. Instead of using the proportionality test, the CFI chose the Walrave doctrine. Within this framework the Court is trapped in a labyrinth of words without real meaning, the most tricky of which being 'sporting purity'. The Court stated that the question was whether the rules were purely sporting in nature or whether they covered the economic aspect of the sporting activity. Therefore it chose to use the Walrave test. As has been seen, the ECJ had refused to apply this analysis in Bosman, Deliège and Lehtonen. The CFI did not understand the message and erred in its interpretation. This is so not only because it was going against the case law of the

\footnotetext{
${ }^{67}$ Case C-309/99, Wouters, n 53 above, § 97.

${ }^{68}$ Case C-415/93, Bosman, n 32 above, § 131.

${ }^{69}$ Fonteneau, M., 'L'exception sportive en droit communautaire', 2001 Gazette du Palais, juillet-août, p. 1276.

70 Whish, n 56 above, p. 122. See also Szyszczak, E. (2007), 'Competition and Sport', European Law Review 32, p. 106; and O'Loughlin, R. (2003), 'EC Competition Rules and Free Movement Rules: An Examination of the Parallels and their Furtherance by the ECJ Wouters Decision', European Competition Law Review 24.

${ }^{71}$ AG Lenz opinion in Case 415/93, Bosman, n 28 above, § 217.
} 
$\mathrm{ECJ}^{72}$ but also because its reasoning lacks clarity. Walrave and Donà were not the result of logical reasoning; rather, they were based on an idea which was not correctly explained. The acceptance of sporting practices which, in principle, are contrary to EC law (but may be justified) cannot be based on a derogation of the Treaty but rather on a flexible interpretation of the rules.

This melange was patently exposed in the judgment of the CFI. The court starts with a false assumption, this is, the existence of purely sporting rules. This type of rules was not acknowledged by the European Court of Justice in any of its previous cases. The Court had only supported the existence of purely sporting interests or made reference to the particular nature of matches. What is therefore a purely sporting rule? The CFI has its own answer: 'rules concerning questions of purely sporting interest and, as such, having nothing to do with economic activity (Walrave, $\S 8)^{\prime}{ }^{\prime 3}$ However Walrave never said that there were no economic effects at all. The ECJ has taken much care avoiding referring to any sporting activity as not having economic effects. As has been said, Walrave was based on the sporting interest, and it did not extend its recognition of purity to the whole activity. Further, if every sporting rule was analysed, the vast majority, or perhaps even all, of them would have effects in the economic sphere. In fact, some authors have affirmed that rules which initially were drawn up for sporting reasons may have assumed greater economic importance. ${ }^{74}$ Moreover the 'rules of the game', which are sometimes considered to be the perfect example of purely sporting rules ${ }^{75}$, carry inescapable economic implications. ${ }^{76}$ Notwithstanding this, the CFI held that 'the prohibition of doping is based on purely sporting considerations and therefore has nothing to do with any economic consideration'. ${ }^{77}$ As has been seen, pure means 'free from anything of a different, inferior, or contaminating kind'. As the Court itself will recognise, the prohibition of doping is far from being considered to be pure.

The Court follows its reasoning by stating that ' $[\mathrm{t}] \mathrm{he}$ fact that purely sporting rules may have nothing to do with economic activity, with the result, according to the Court, that they do not fall within the scope of Articles $39 \mathrm{EC}$ and $49 \mathrm{EC}$, means, also, that they have nothing to do with the economic relationships of competition, with the result that they also do not fall within the scope of Articles $81 \mathrm{EC}$ and $82 \mathrm{EC}^{\prime} .^{78}$ If the first premise is wrong, and it is, then it could be affirmed that the inference of the Court is not accurate. Even the Court contradicts its findings when it says that '[i]t is precisely because sporting rules have economic repercussions for professional sportsmen and sportswomen and because those rules are considered to be excessive by some of those professionals that the dispute arises' ${ }^{79}$ Thus, if the dispute arises it is because the rule has economic repercussions. The CFI however does not accept this view and goes against its own reasoning by rejecting the allegations of the parties concerning the existence of economic factors. As has been seen, the Court affirmed that the prohibition of doping had nothing to do with any economic consideration. The parties alleged however that the International Olympic Committee (IOC) had an economic interest in approving antidoping regulations. The Court, surprisingly, affirmed that the 'IOC might possibly have had in mind [...] the concern [...] of safeguarding the economic potential of the Olympic Games'. ${ }^{80}$ However the CFI stated that this was not sufficient to alter the purely sporting nature of those rules. And, more surprisingly, that even were it was 'proved, quod non, that the IOC acted exclusively on the basis of its purely economic interests, there [was] every reason to believe that it fixed the limit at the level best supported

\footnotetext{
72 Weatherill, S. (2005), 'Anti-Doping Rules and EC Law', European Competition Law Review 26, p. 420 supporting the use of the Court's formula in Wouters.

${ }^{73}$ Case T-313/02, Meca Medina v Commission, n 51 above, $\S 41$.

${ }^{74}$ Parrish, n 44 above, p. 118.

75 The CFI refers to the rules of the game 'in the strict sense, such as, for example, the rules fixing the length of matches or the number of players on the field, given that sport can exist and be practised only in accordance with specific rules'. Case T-313/02, Meca Medina v Commission, n 51 above, § 41.

${ }^{76}$ Weatherill, S. (2003), 'Fair Play Please: Recent Developments in the Application of EC Law to Sport', Common Market Law Review, no 40, p. 81.

${ }_{77}$ Case T-313/02, Meca Medina v Commission, n 51 above, $\S 47$.

78 ibid, $\$ 42$.

79 ibid, § 53.

80 ibid, § 57.
} 
by the scientific evidence'. ${ }^{81}$ To simplify, what the Court says is (1) that there is no economic activity; (2) that the concern of safeguarding the economic potential of the competition is not relevant; and (3) that even if it was proven that there were purely economic interests, the rule had been correctly drafted. It is clear that one cannot say at the same time that something is purely sporting if it has been conceived on the basis of purely economic interests. It is either purely sporting or not. As has been said, any attempt to present the rules as 'sporting' and not 'economic' is unhelpful, because they are both. ${ }^{82}$ The concept of sporting purity should be erased from the wording of the judgments of the Court. As mentioned above, there are very few, if any, rules that can be considered as purely sporting in nature. What the courts should do instead is to analyse if the sporting rule is justified.

\section{Phase 4: Withdrawal?}

The judgment of the CFI in Meca Medina reflects the ambiguity of the basis for recognising the sporting exemption. There are no clear limits within which the sporting bodies or the EC institutions could take their decisions and develop their activities. Therefore there is a need to either clarify the scope of the exemption or withdraw it. In our view the first possibility should be rejected since the Walrave doctrine cannot have a rational explanation. The judgment of the ECJ in Meca Medina could be seen as an answer in line with the second option. It could be said that the ECJ has withdrawn the sporting exemption. However the wording of the judgment is not clear enough to clarify the issue. It has shed light on certain aspects but others are still unresolved. Anyhow, the Court was conscious of the importance of the subject and, relying upon Article 61 of the Statute of the Court, gave a judgment on the substance of the case. ${ }^{83}$

The judgment can be welcomed in part. The Court finally recognised that the sporting exemption has nothing to do with the concept of economic activity. What it represents, in fact, is a rejection of the sporting exemption as framed in Walrave. The ECJ affirmed that 'the mere fact that a rule is purely sporting in nature does not have the effect of removing from the scope of the Treaty the person engaging in the activity governed by that rule or the body which has laid it down'. ${ }^{84}$ Further, '[i]f the sporting activity in question falls within the scope of the Treaty [i.e. because it constitutes an economic activity within the meaning of Article 2 $\mathrm{EC}]$, the conditions for engaging in it are then subject to all the obligations which result from the various provisions of the Treaty'. ${ }^{55}$ So the Court is virtually saying that the interpretation of Walrave and Donà can no longer be sustained. The message of the Court is that the concept of economic activity has nothing to do with the sporting exemption. If the activity is economic, then the exemption cannot be granted. The notion of sporting purity is therefore irrelevant to the question of the applicability of EC competition rules to the sporting sector. ${ }^{86}$ Furthermore, a general exemption of sporting rules or of activities of sports associations is therefore neither possible nor warranted. ${ }^{87}$

The findings of the Court are also relevant in relation to the use of the proportionality test. The Court confirmed that in order to analyse the compatibility of sporting rules with Art. 81 EC there is a need to resort to Wouters and DLG:

'[...] the compatibility of rules with the Community rules on competition cannot be assessed in the abstract (see, to this effect, Case C-250/92 DLG [1994] ECR I-5641, paragraph 31). Not every agreement between undertakings or every decision of an

\footnotetext{
81 ibid, § 58.

82 See Weatherill, S. (2006), 'Anti-doping revisited-the demise of the rule of 'purely sporting interest'?', European Competition Law Review 12, p. 648.

${ }^{83}$ Szyszczak, n 70 above, p. 104.

${ }^{84}$ Case C-519/04, Meca-Medina [2006] ECR I-6991, § 27.

85 ibid, § 28.

${ }^{86}$ European Commission (2007), White Paper on Sport, COM 391 final, p. 14.

87 European Commission (2007), Commission Staff Working Document. The EU and Sport: Background and Context, SEC 935, p. 69.
} 
association of undertakings which restricts the freedom of action of the parties or of one of them necessarily falls within the prohibition laid down in Article 81(1) EC. For the purposes of application of that provision to a particular case, account must first of all be taken of the overall context in which the decision of the association of undertakings was taken or produces its effects and, more specifically, of its objectives. It has then to be considered whether the consequential effects restrictive of competition are inherent in the pursuit of those objectives (Wouters and Others, paragraph 97) and are proportionate to them. ${ }^{188}$

This finding, which is in accordance with the line of reasoning of the Advocates General in Bosman, Deliège and Lehtonen, has been acknowledged by the European Commission in its White Paper on Sport. As the Commission explains, there are organisational sporting rules that are likely not to breach the anti-trust provisions of the EC Treaty, provided that their anticompetitive effects, if any, are inherent and proportionate to the objectives pursued. ${ }^{89}$ The consequence of this is that the assessment of whether a certain sporting rule is compatible with EC competition law can only be made, under a rule of reason analysis, on a case-by-case basis.

The judgment however lacks clarity in a number of matters. On the one hand the Court makes a reference to its first seminal judgments (Walrave and Donà). However its conclusion is that the fact that a rule is purely sporting is not relevant in relation to removing it from the scope of the Treaty. Does this mean that being purely sporting is no longer relevant at all? Or does it mean that being purely sporting is not relevant in this particular case? If being purely sporting is not relevant, why does the Court then quote its findings in Walrave and Donà? Furthermore, what is, for the Court, a purely sporting rule?

In addition, the Court introduced more uncertainty in relation to a subject which, until then, had not been brought into question. According to the practice of the Commission, the sporting exemption applied equally to internal market and competition rules. The ECJ however affirmed that 'therefore, even if those rules do not constitute restrictions on freedom of movement because they concern questions of purely sporting interest and, as such, have nothing to do with economic activity (Walrave and Donà), that fact means neither that the sporting activity in question necessarily falls outside the scope of Articles $81 \mathrm{EC}$ and $82 \mathrm{EC}$ nor that the rules do not satisfy the specific requirements of those articles'. ${ }^{90}$ What this means is that the sporting exemption will be applied differently in the competition field than in the internal market area. ${ }^{91}$

\section{Conclusions}

In 1974 The European Court of Justice adopted a decision which would influence the treatment of sport by the European institutions. The Court might not at the time have been aware of the consequences of its judgment. Now, more that thirty years later, it could be said that the Court has to a greater or lesser extent acknowledged its error. Walrave had farreaching effects that the Court tried to contain; but this reaction came late. Indeed the Court confirmed its findings in Donà before taking action. Furthermore the Court did not choose the best way to contain the effects of the sporting exemption. Instead of modifying its line of reasoning, the ECJ tried to cover up the effects of its case law by not applying its principles to the cases that arose subsequently. This behaviour had two effects. Firstly, the sporting exemption was considered as a real possibility. The fact that the Court made reference in its 'contention cases' (Bosman, Deliège and Lehtonen) to the principles established in Walrave and Dona led the Commission and the sporting bodies to believe that sport was, to a certain extent, out of the reach of the Treaty. Consequently the sporting exemption extended from internal market to competition rules.

\footnotetext{
${ }^{88}$ Case C-519/04, Meca-Medina, n 84 above, § 42.

${ }^{89}$ European Commission, White Paper on Sport, n 86 above, p. 13.

${ }^{90}$ Case C-519/04, Meca-Medina, n 84 above, § 31.

${ }^{91}$ See Weatherill, n 82 above, pp. 649 and 650 for a different opinion.
} 
Walrave might be based on a logical assumption but the explanation behind it was wrong. An ex post analysis of the circumstances leads us to affirm that in 1974 the ECJ acted instinctively. It saw where the conflict lay and the proper solution but did not construct an appropriate discourse. It is true that, in certain cases, the rules of the Treaty cannot be applied. This is clearly the case if they are going to jeopardise the very existence or the fundamental principles of the sport. However one cannot say that this is necessarily so because the rules are purely sporting and this means that there are no economic elements involved. The analysis to be implemented should be based on the necessity and adequacy of the sporting rule. The test to ascertain which sporting practices are compatible with the Treaty articles on free movement and competition law should be the proportionality test. In relation to internal market rules this could amount to the analysis of the existence of mandatory requirements of general interest or objective justifications. In the case of EC competition law this will amount to the use of the Wouters formula (qualitative appreciability or rule of reason). The case law should address these issues, and clearly reject the existence of a sporting exemption. Meca Medina could be seen, in this connection, as a first step in the converging analysis of sporting practices under internal market and competition law. The findings of the Court are remarkably similar to the analysis performed to assess the compatibility of sporting practices with the rules of the internal market in other cases related to sport. In fact, Deliège and Meca Medina are strikingly similar. In this connection Deliège is an example of how the Court should act when analysing the compatibility of sport rules with the Treaty when using the proportionality test. A flexible interpretation of the objective justification test is indeed the way to deal with this issue. It is interesting to see how flexible the view of the $\mathrm{ECJ}$ is in this case in comparison with the strict analysis adopted in Bosman.

The Court should give a definite decision. In the analysis of the CFI in Meca Medina it has been seen how difficult is to adopt a correct answer when dealing with the principles established in Walrave and Donà. It is impossible to find a logical outcome if one tries to fit together the findings of the Court on the sporting exemption, the internal market and competition regimes and the reality of the sporting world. Oulmers could be a good opportunity to reject the sporting exemption, as, although the case deals with 'matches between national teams from different countries' (Donà), the Court cannot claim that there are no economic elements involved. However, in this case and others, the Court should be open minded, and should assume that the sporting bodies have the necessary knowledge and experience, being best placed to adopt adequate rules.

In any event, since Meca Medina the sporting associations do at least have more legal certainty than before. Now they should be secure in the knowledge that, in relation to the compatibility with EC law, their actions will be assessed on a case-by-case basis. That is the view of the European Commission in its White Paper on Sport. Whether sporting bodies will be happy with this is, of course, another question altogether. 